OPEN ACCESS

Citation: Wong Sin Yeng, Peter C. Boyce, Hoe Yin Chen (2021) Studies on Schismatoglottideae (Araceae) of Peninsular Malaysia III: New species for the Schismatoglottis Calyptrata Clade. Webbia. Journal of Plant Taxonomy and Geography 76(2): 245-259. doi: 10.36253/jopt-11285

Received: June 2, 2021

Accepted: June 24, 2021

Published: September 7, 2021

Copyright: @2021 Wong Sin Yeng, Peter C. Boyce, Hoe Yin Chen. This is an open access, peer-reviewed article published by Firenze University Press (http://www.fupress.com/webbia) and distributed under the terms of the Creative Commons Attribution License, which permits unrestricted use, distribution, and reproduction in any medium, provided the original author and source are credited.

Data Availability Statement: All relevant data are within the paper and its Supporting Information files.

Competing Interests: The Author(s) declare(s) no conflict of interest.

Editor: Alistair Hay

ORCID

WSY: https://orcid.org/0000-0003-40429672

PCB: https://orcid.org/0000-0002-5856-

9561

HYC: https://orcid.org/0000-0001-91239751

\section{Studies on Schismatoglottideae (Araceae) of Peninsular Malaysia III: New species for the Schismatoglottis Calyptrata Clade}

\author{
Wong Sin Yeng ${ }^{1,2,3, *}$, Peter C. Boyce 3 , Hoe Yin Chen ${ }^{4}$ \\ ${ }^{1}$ Institute of Biodiversity and Environmental Conservation, Universiti Malaysia Sarawak, \\ 94300 Kota Samarahan, Sarawak, Malaysia \\ ${ }^{2}$ Harvard University Herbaria, 22 Divinity Avenue, Cambridge, MA 02138, USA \\ ${ }^{3}$ Department Biologie I, Systematische Botanik und Mykologie, Ludwig-Maximilians-Uni- \\ versität München, München, Germany \\ ${ }^{4}$ Tunku Abdul Rahman University College, Johor Branch Campus, Johor, Malaysia \\ *Corresponding author. E-mail: sywong@unimas.my
}

\begin{abstract}
Three new colonial species of Schismatoglottis Calyptrata clade are described from Peninsular Malaysia and compared with the four already known morphologically similar species described from there. All seven species are illustrated from living plants and an identification key is provided.
\end{abstract}

Keywords: Araceae, Schismatoglottis, Calyptrata clade, Peninsular Malaysia.

\section{INTRODUCTION}

With the exclusion of Schismatoglottis calyptrata (Roxb.) Zol. \& Moritzi (sensu Hay 1996; Hay in Hay and Yuzammi 2000) from the flora of Peninsular Malaysia (Wong et al. 2018; Wong and Boyce 2020) the Schismatoglottis Calyptrata Clade (Wong et al. 2016, 2018) is currently represented in the Malay Peninsula by four described species: Schismatoglottis cordifolia Ridl. (Ridley 1911: 112; Figures 1 and 10B), S. guabatuensis S.Y.Wong \& P.C.Boyce (Wong and Boyce 2020: 1; Figure 10C), S. lowiae S.Y.Wong \& P.C.Boyce (Wong and Boyce 2017: 31; Figures 2 and 10E), and S. wallichii Hook.f. (Hooker 1893: 537; Figs. 3 and 10G). During pollination biology studies by the third author (Hoe and Wong 2016; Hoe et al. 2018, 2020; Wong et al. 2016) it became evident that several populations encountered did not correspond to any of these four species, nor did they match any described species from Sumatera or further east. In conclusion we consider these populations to represent undescribed species and here describe three novel Peninsula Malaysian species belonging in the Calyptata clade. Geology in this paper is specified based on Tate et al. (2008). 

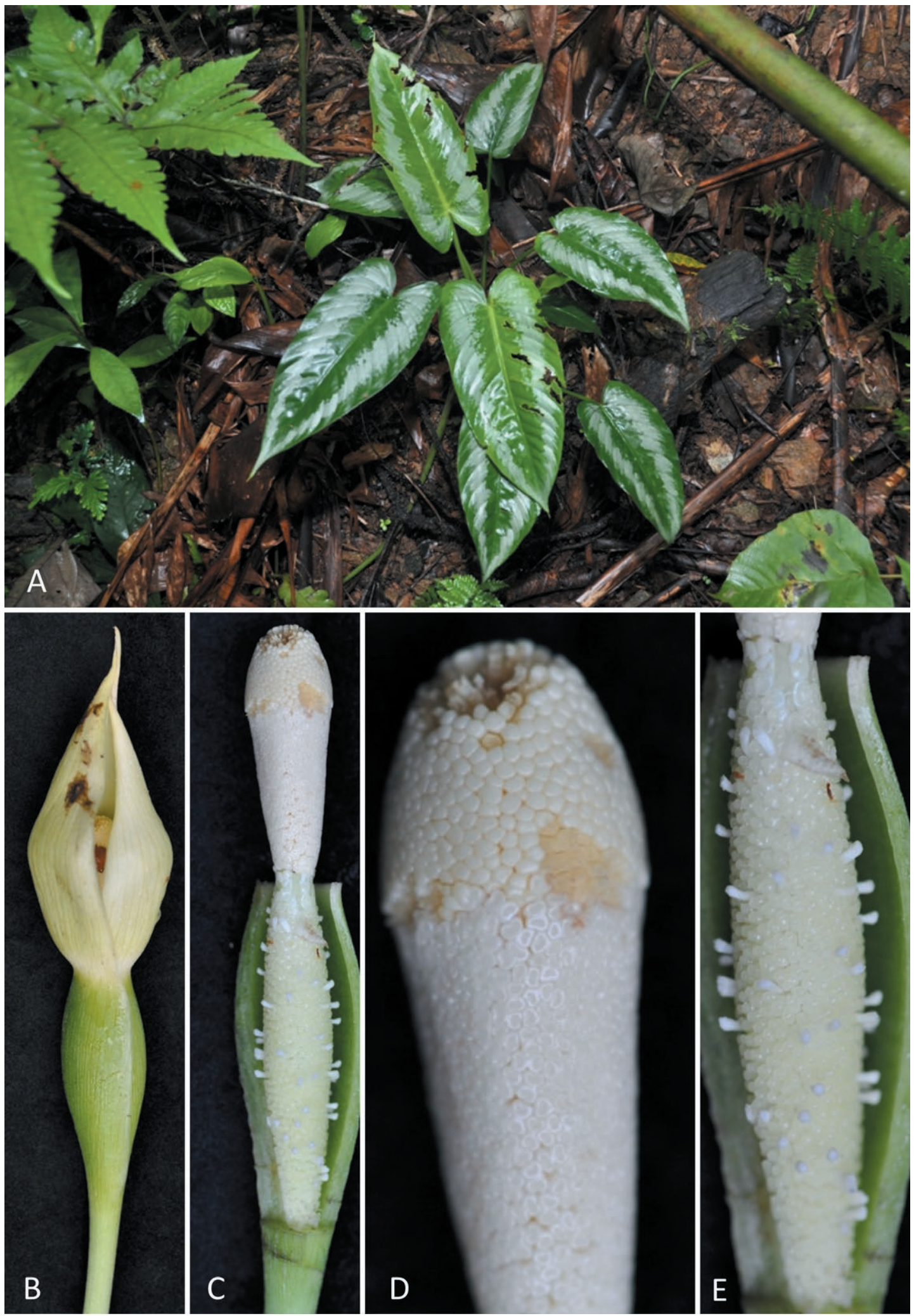

Figure 1. Schismatoglottis cordifolia Ridl. A. Plant in habitat. B. Bloom at pistillate anthesis. C. Bloom at pistillate anthesis, spathe limb naturally shed, nearside of lower spathe artificially removed. D. Detail of appendix and staminate florets. E. Detail of pistillate zone and interstice, nearside lower spathe artificially removed. All from Zalhazman bin Hamzah s.n. 

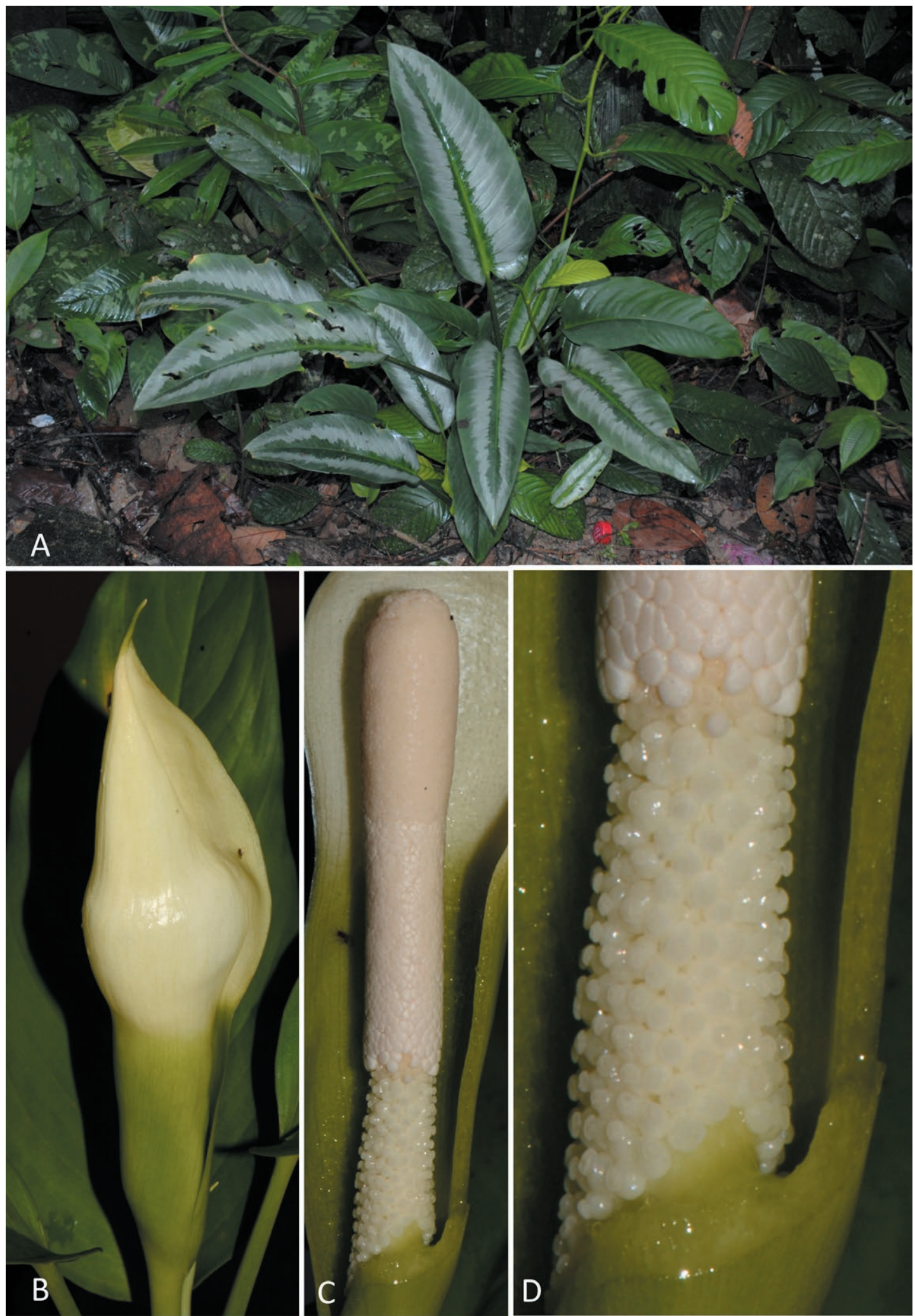

Figure 2. Schismatoglottis lowiae S.Y.Wong \& P.C.Boyce. A. Plant in habitat. B. Bloom at pistillate anthesis. C. Bloom at pistillate anthesis, nearside of spathe artificially removed. D. Detail of pistillate zone and interstice, nearside lower spathe artificially removed. All from AR-3286. 


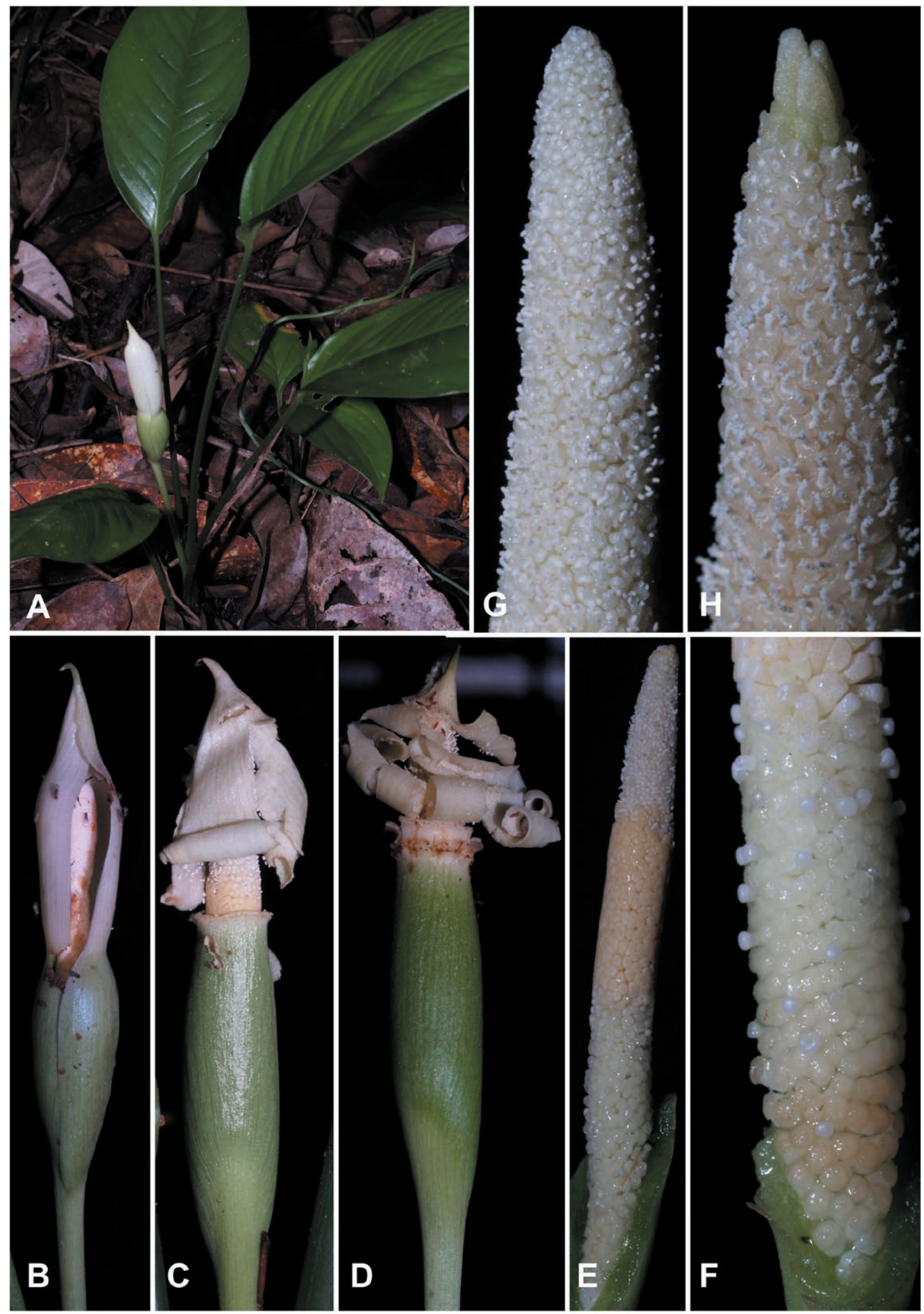

Figure 3. Schismatoglottis wallichii Hook.f. A. Plant in habitat. B. Bloom at pistillate anthesis. C. Bloom at onset of staminate anthesis, spathe limb beginning to shed. D. Bloom at late staminate anthesis, spathe limb splitting into numerous circumferential pieces. E. Spadix at pistillate anthesis, spathe artificially removed. F. Pistillate floret zone. G. \& H. Staminate zone fertile to tip (G) and with a few terminal staminodes (H). A-G from AR-16; H from AR-762. 
Schismatoglottis caesia S.Y.Wong, P.C.Boyce \& Y.C.Hoe, sp. nov.

Type: Malaysia, Kelantan, Gua Musang, Kuala Koh, Taman Negara Kuala Koh, $4^{\circ} 52.333^{\prime} \mathrm{N} 102^{\circ} 26.872^{\prime} \mathrm{E}, 11$ Jan 2014, Hoe Yin Chen AR-4332 (holotype KEP; isotype SAR). (Figures 4, 5 and 10A).

\section{Diagnosis}

Schismatoglottis caesia is immediately differentiated from all other species of the Schismatoglottis Calyptrata clade by the glaucous pale grey leaf blades.

\section{Description}

Medium sized moderately robust, evergreen, stoloniferous colonial herb, $20-60 \mathrm{~cm}$ tall. Stems hypogeal, hapaxanthic, $0.8-1.8 \mathrm{~cm}$ diam. Leaves 3-6 together; petiole D-shaped, smooth, $15-19 \mathrm{~cm}$ long, slightly channelled along its length, green, distally with darker longitudinally broken-striate striations; petiolar sheath, 8 $\mathrm{cm}$ long $\times 0.5$ wide, sheathing for $2 / 5$ of petiole length, persistent, membranous, fully attached with a very short ligule, equal on both sides, slightly in rolled or sometimes straight, tapering, green with scattered greenish striate dotting; blades ovato-sagittate to ovato-cordate (sometimes oblong-lanceolate with the base cordate), $17.5-19 \mathrm{~cm}$ long $\times 7-10.5 \mathrm{~cm}$ wide, weakly coriaceous, glaucous pale grey, posterior lobes subtriangular, 3-4.5 $\mathrm{cm}$ long, sinus $4-5.5 \mathrm{~cm}$ across, apex of anterior lobe acute for $2-3 \mathrm{~cm}$, ultimately mucronate for $2.5 \mathrm{~mm}$; midrib adaxially flush with blade, raised abaxially, 3.5 $\mathrm{mm}$ wide at the insertion of the leaf blade; primary lateral veins 16 per side, diverging at $30^{\circ}-80^{\circ}$ from the midrib, raised adaxially towards the midrib, marginally impressed, entirely raised abaxially; interprimary veins raised adaxially, alternating irregularly with primaries; few (0-2) secondary veins emerging from each primary veins (3-4 from primary veins near to insertion); pellucid canals inconspicuous. Blooms 1-3 in a synflorescence, erect at anthesis, emitting an esteric smell during pistillate anthesis, odour absent during staminate anthesis; peduncle $10-12 \mathrm{~cm}$ long $\times 4-8 \mathrm{~mm}$ diam., terete, green; spathe $12 \mathrm{~cm}$ long; lower spathe narrowly ovoid, $4.8 \mathrm{~cm}$ long $\times 1.8 \mathrm{~cm}$ wide, green, externally longitudinally ridged, separated from spathe limb by a constriction coinciding with lower staminate zone; spathe limb pale greenish yellow and turbinate at anthesis, $7 \mathrm{~cm}$ long $\times 3.8 \mathrm{~cm}$ wide, mucronate for $4.5 \mathrm{~mm}$, slightly paler prior to staminate anthesis, caducous in a single piece at the onset of staminate anthesis; spadix $8 \mathrm{~cm}$ long, shorter than spathe, sessile; pistillate zone fusiform, 4 $\mathrm{cm}$ long $\times 8 \mathrm{~mm}$ wide, $1 / 2$ length of spadix, light green; pistils sub-cylindric to sub-globose, $1.5-2 \mathrm{~mm}$ long $\times$ $0.6-1 \mathrm{~mm}$ wide, densely arranged; style barely differentiated; stigma sub-globose, truncate, narrower than ovary, $0.3 \mathrm{~mm}$ diam., wet with stigmatic secretion at the onset of pistillate anthesis; interpistillar staminodes scattered, slightly exceeding the pistils in height, clavate, stipe hardly differentiated, tip about $0.5 \mathrm{~mm}$ in diam., white; interstice sub-cylindric, $0.5-0.8 \mathrm{~cm}$ long $\times 5 \mathrm{~mm}$ wide, narrower than pistillate and staminate zones, partially naked occupied by scattered flattened pistils, with 1 whorl of flattened spherical staminodes in the distal part, these intergrading into the lower staminate zone, pistillodes flattened in proximal part of interstice; staminate zone sub-cylindric, narrower at proximal end, wider at distal end, $1.5-2 \mathrm{~cm}$ long $\times 8-10 \mathrm{~mm}$ wide, $1 / 4$ length of spadix, yellowish white; staminate florets 1 $\mathrm{mm}$ long $\times 0.5 \mathrm{~mm}$ wide, butterfly-shaped from above, densely arranged, each comprising 2 truncate stamens, tops depressed, overtopped by a broad, raised connective; pollen powdery, white; appendix bullet-shaped, $1.3-1.5 \mathrm{~cm}$ long $\times 1 \mathrm{~cm}$ wide, about $1 / 5$ length of spadix, slightly wider $(0.2-0.5 \mathrm{~mm})$ than the top of staminate zone, yellowish white; staminodes polygonal, sub-globose towards the tip of the appendix, $2 \mathrm{~mm}$ long $\times 0.5$ $\mathrm{mm}$ wide, densely arranged. Infructescences $1-3$, fruiting part $4.5 \mathrm{~cm}$ long $\times 2 \mathrm{~cm}$ wide, on declinate peduncles; lower spathe entirely persistent, splitting and reflexing downwards when at fruit maturity; fruits $3 \mathrm{~mm}$ long $\times 1-2 \mathrm{~mm}$ wide, light yellow; seeds ovoid ellipsoid, longitudinally ridged, $0.4 \mathrm{~mm}$ diam., encased in yellow gel.

\section{Etymology}

The specific epithet is derived from the Latin noun, 'caesius', bluish grey, referring to the unique colouration of the leaf blades.

\section{Distribution}

Schismatoglottis caesia is only known from two populations in east Kelantan, separated by about $120 \mathrm{~km}$.

\section{Ecology}

Perhumid lowland tropical forests, on alluvial sandstone-derived mud overlying Triassic granite, along track margins and on steep slopes along the margins of streams, $50-100 \mathrm{~m}$ asl.

\section{Notes}

The glaucous leaf blades of Schismatoglottis caesia are highly distinctive, even sterile juvenile plants are readily identifiable and immediately distinguished from the co-occurring S. lowiae. The type population occurs 

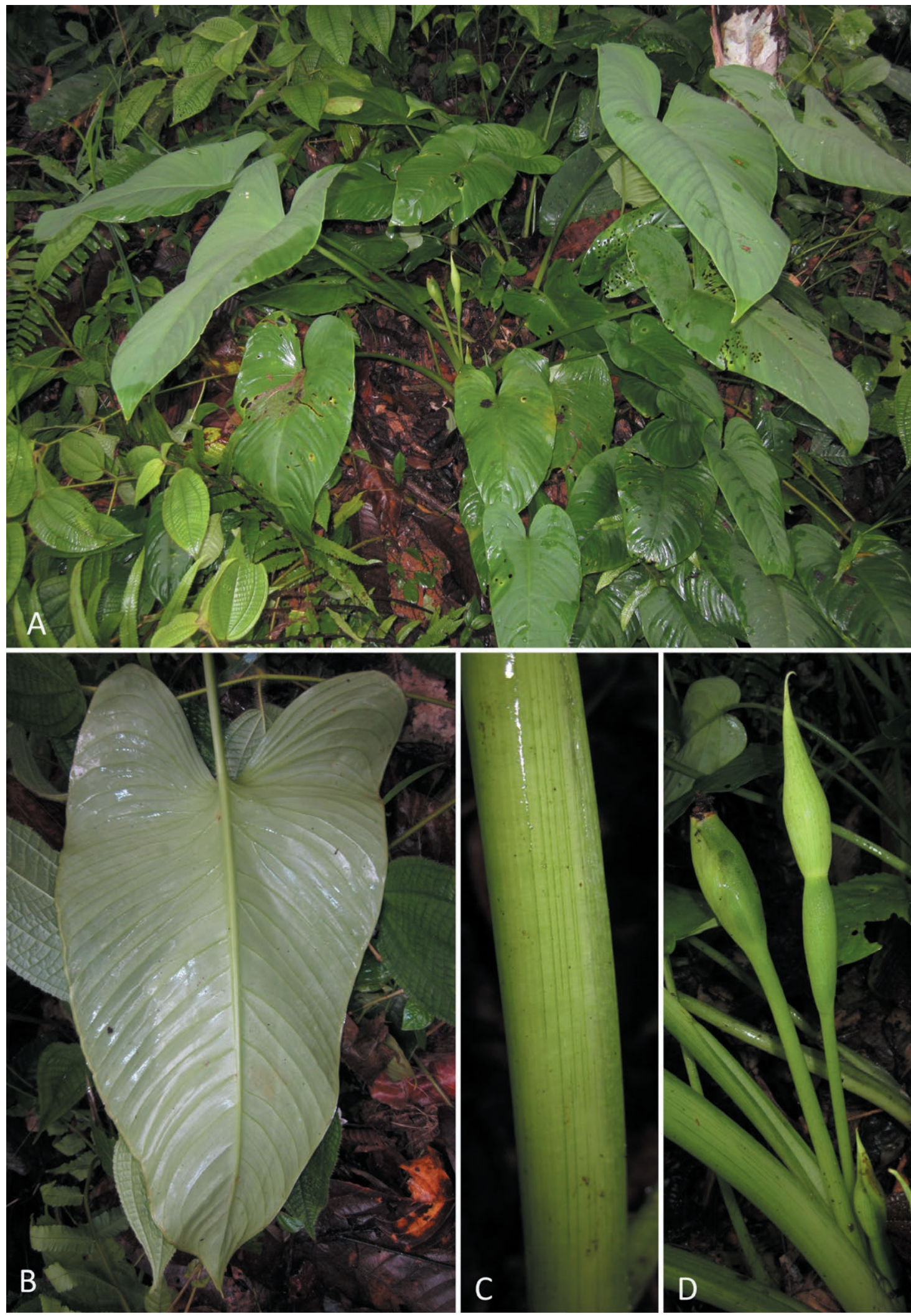

Figure 4. Schismatoglottis caesia S.Y.Wong, P.C.Boyce \& Y.C.Hoe. A. Plant in habitat. B. Leaf blade abaxial surface. C. Detail of petiole. D. Synflorescence showing sequential development (left to right). All from AR-4332. 


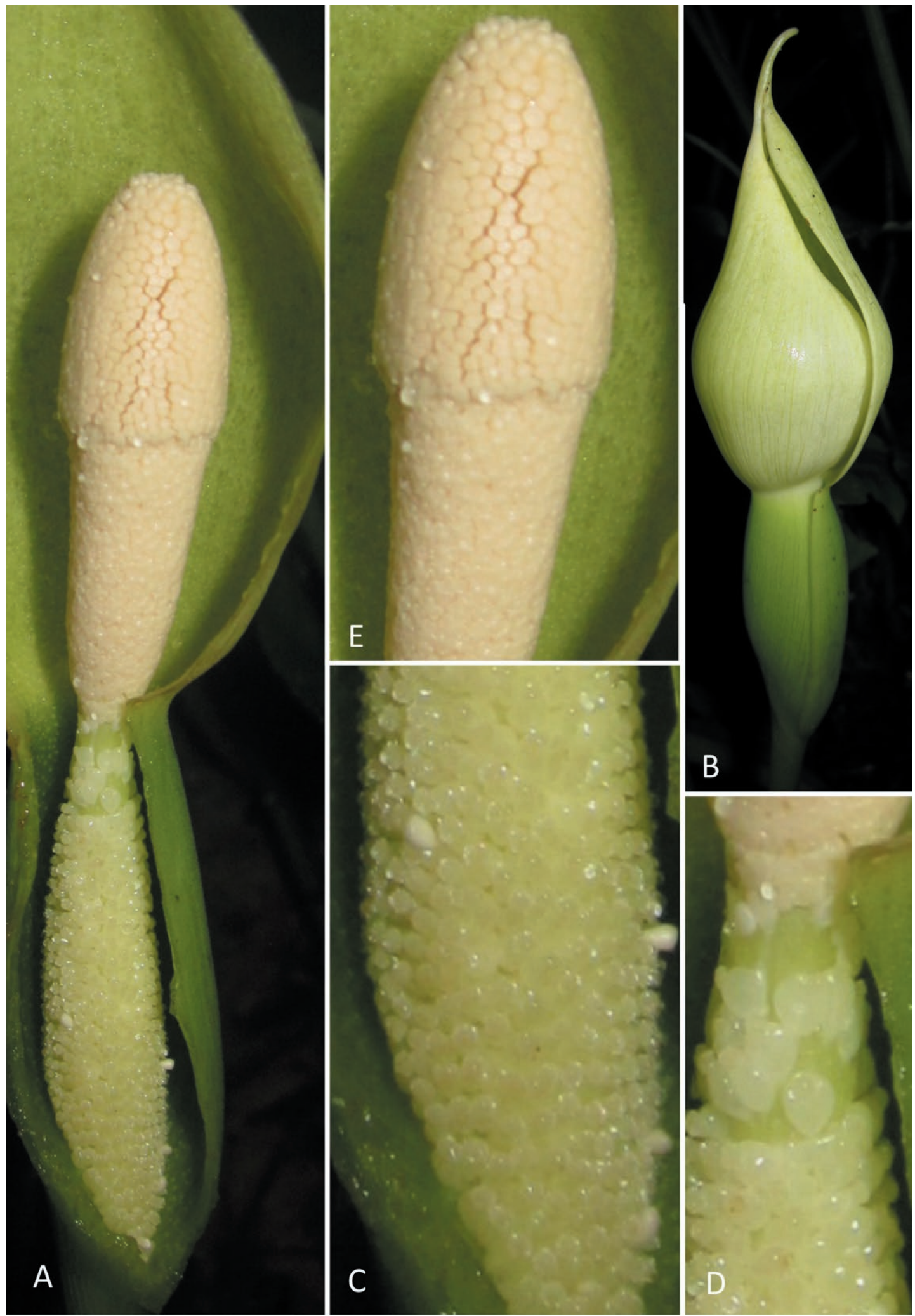

Figure 5. Schismatoglottis caesia S.Y.Wong, P.C.Boyce \& Y.C.Hoe. A. Bloom at pistillate anthesis, nearside spathe artificially removed. B. Bloom at pistillate anthesis. C. Detail of pistillate zone. D. Detail of upper part of pistillate zone, interstice with flattened staminodes, and lowermost part of staminate zone. E. Appendix and upper part of staminate zone. All from AR-4332. 
adjacent to (although not associated with) OrdovicianDevonian Karst, suggesting that the species is not able to colonize karst. By the same token there are species in the Calyptrata clade (e.g., S. guabatuensis) that never occur away from limestone. Such geological obligations appear to be a contributing factor behind the high species diversity that aroids, and several other herbaceous and woody plant families, display in SE Asia (e.g., Wong and Boyce 2021).

\section{Additional specimens examined (paratypes)}

MALAYSIA. Kelantan. Tanah Merah, Hulu Kusial, Gua Ipoh, Lata Hujan, 543'53.1”N 10201'03.5”E, 16 Mar 2016, Wong Sin Yeng \& P.C. Boyce AR-3317 (KEP, SAR) \& Wong Sin Yeng \& P.C. Boyce AR-3318 (KEP, SAR); Tanah Merah, Jedok, Kampung Lawang, Lata Bijih, $5^{\circ} 43^{\prime} 54.37^{\prime \prime N} 102^{\circ} 0^{\prime} 58.80^{\prime \prime}$ E, 16 Mar 2016, Wong Sin Yeng \& P.C.Boyce AR-3322 (KEP, SAR).

\section{Schismatoglottis laxipistillata S.Y.Wong, P.C.Boyce \& Y.C.Hoe, sp. nov.}

Type: Malaysia, Kedah, Merbok Division, Bedong, Hutan Lipur Rekreasi Tupah Merbok, just outside the entrance, beside the boundary of a quarry,

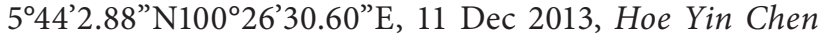
AR-4331 (holotype SAR; isotype KEP). (Figures 6, 7 and 10D).

\section{Diagnosis}

Schismatoglottis laxipistillata is distinguished from the other species in the Calyptrata Clade by its laxly arranged pistils.

\section{Description}

Medium to moderately robust, evergreen, stoloniferous herb forming clumps, $35-40 \mathrm{~cm}$ tall. Stems hypogeal, hapaxanthic, 1-2 cm diam. Leaves 3-8 together; petiole D-shaped, smooth, $18-20 \mathrm{~cm}$ long, white to very pale green, weakly channelled for $1 / 2$ its length, longitudinal striations raised distally, darker green; petiolar sheath 5-8 cm long $\times 0.5-1 \mathrm{~cm}$ wide, sheathing for $1 / 3$ of petiole length, persistent, membranous, fully attached with a very short ligule, equal at both sides, slightly inrolled or sometimes straight, tapering, green with scattered greenish broken-striate; blades ovato-sagittate to ovato-cordate (sometimes oblong-lanceolate with the base cordate), $29 \mathrm{~cm}$ long $\times 16 \mathrm{~cm}$ wide, weakly coriaceous, adaxially dull green, some plants variegated with spattered grey-green central stripes, abaxially paler, posterior lobes subtriangular, $3.5-5 \mathrm{~cm}$ long, sinus $3-7$ $\mathrm{cm}$ across, apex of anterior love acute for $2 \mathrm{~cm}$, ultimately mucronate for $3 \mathrm{~mm}$; midrib adaxially flush with blade, raised abaxially, $4 \mathrm{~mm}$ at insertion; primary lateral veins 13 per side, diverging at $30^{\circ}-80^{\circ}$ from the midrib, raised adaxially towards the midrib, marginally impressed, entirely raised abaxially; interprimary veins raised adaxially, alternating irregularly with primaries; few (0-2) secondary veins from each primary veins (1-2 arising from primary veins near to insertion); tertiary veins inconspicuous; vein-like pellucid canals not visible. Inflorescences up to five in a synflorescence, erect, emitting an esteric smell during pistillate anthesis-but not during staminate anthesis; peduncle $8-16 \mathrm{~cm}$ long $\times 3-8 \mathrm{~mm}$ wide, terete, green, erect at anthesis; spathe $10.5 \mathrm{~cm}$ long; lower spathe narrowly ovoid, $4.2 \mathrm{~cm}$ long $\times 2 \mathrm{~cm}$ wide, green, externally longitudinally ridged, separated from spathe limb by a constriction coinciding with the interstice; spathe limb turbinate, $6.5 \mathrm{~cm}$ long $\times 3.5 \mathrm{~cm}$ wide, mucronate for $3 \mathrm{~mm}$, pale greenish yellow at pistillate anthesis, slightly pallid prior to staminate anthesis, caducous in a single piece at onset of staminate anthesis; spadix $8.5 \mathrm{~cm}$ long, shorter than spathe, sessile; pistillate zone fusiform, $4 \mathrm{~cm}$ long $\times$ $7 \mathrm{~mm}$ wide, $1 / 2$ length of spadix, light green; pistils sub-cylindric to sub-globose, $1.5 \mathrm{~mm}$ long $\times 0.5-1 \mathrm{~mm}$ wide, laxly arranged; style barely differentiated; stigma globose from above, truncated, smaller than ovary, 0.3 $\mathrm{mm}$ diam., wet with stigmatic secretion at the onset of pistillate anthesis; interpistillar staminodes clavate, stipe slender, $0.5 \mathrm{~mm}$ in diam., only slightly taller than pistils, scattered, white; interstice sub-cylindric, 0.6-1 $\mathrm{cm}$ long $\times 5 \mathrm{~mm}$ wide, more slender than pistillate and staminate zone, partially naked with a few flattened irregular closely packed spheroid staminodes at the distal end, partially intergrading into the lower staminate zone, and with a few flattened pistillodes at the proximal end; staminate zone obconic, $1.8 \mathrm{~cm}$ long $\times 10 \mathrm{~mm}$ wide, $1 / 4$ length of spadix, yellowish white; staminate florets $1 \mathrm{~mm}$ long $\times 0.5 \mathrm{~mm}$ wide, butterfly-shaped from above, densely arranged, each comprising 2 truncate stamens, with a broad connective, densely arranged, yellowish white; pollen powdery, white; appendix bulletshaped, $1.6 \mathrm{~cm}$ long $\times 1 \mathrm{~cm}$ wide, $1 / 5$ length of spadix, equal or weakly $(0.2 \mathrm{~mm})$ wider than apex of staminate zone, yellowish white; staminodes sub-globose to polygonal, $2 \mathrm{~mm}$ long $\times 0.4-1 \mathrm{~mm}$ wide, densely arranged. Infructescences 1-5 together, persistent spathe $5 \mathrm{~cm}$ long $\times 2 \mathrm{~cm}$ wide, declinate; lower spathe entirely persistent, splitting from the top with segments reflexed when ripe; fruits $3 \mathrm{~mm}$ long $\times 1-2 \mathrm{~mm}$ wide, light yellow; seeds ovoid ellipsoid, $0.4 \mathrm{~mm}$ diam., 4-8 per fruit, with greenish yellow gel. 


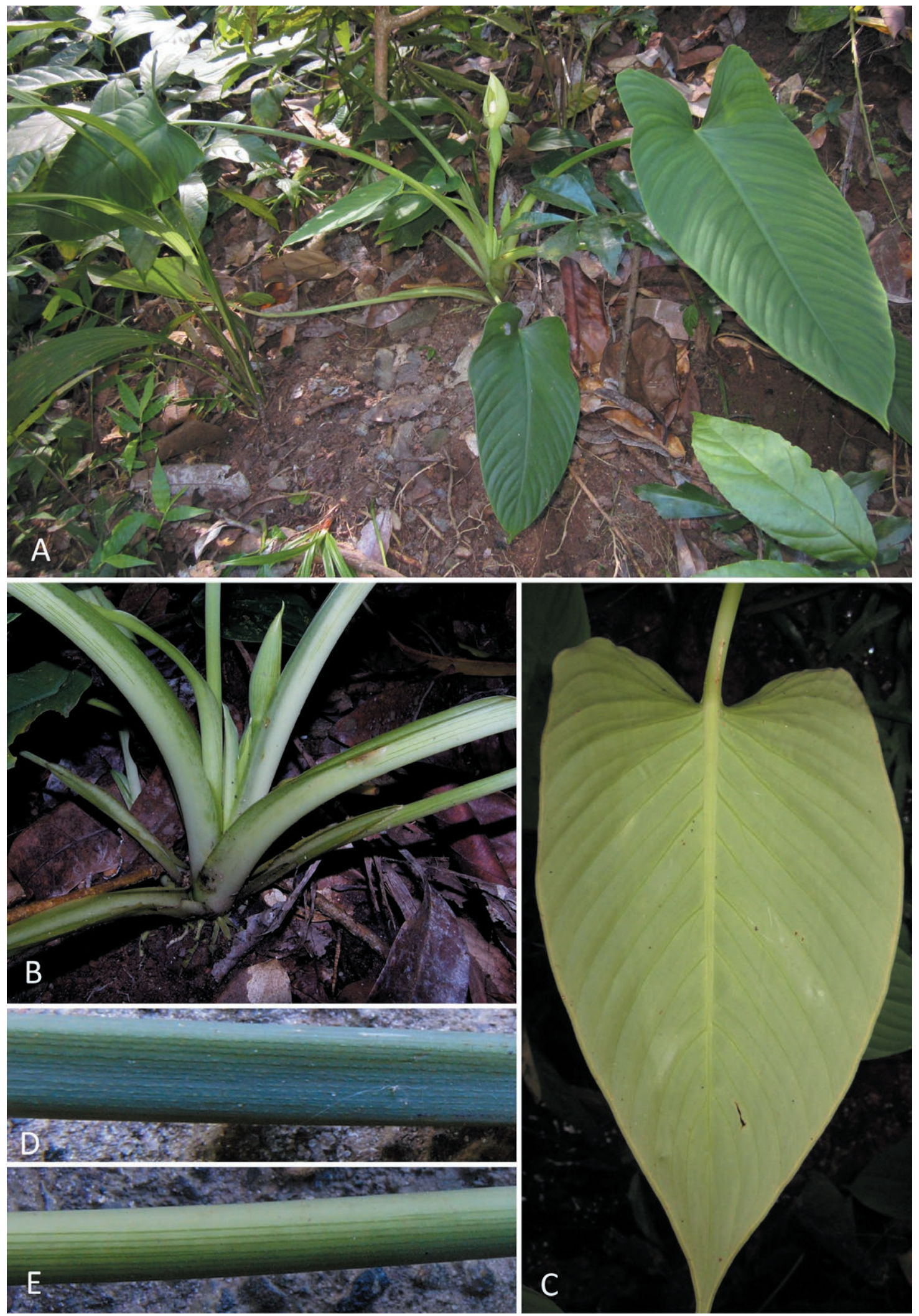

Figure 6. Schismatoglottis laxipistillata S.Y.Wong, P.C.Boyce \& Y.C.Hoe. A. Plant in habitat. B. Base of plant with emerging bloom. C. Leaf blade abaxial surface. D. \& E. Detail of upper portion (D) and lower portion (E) of petiole. All from AR-4331 


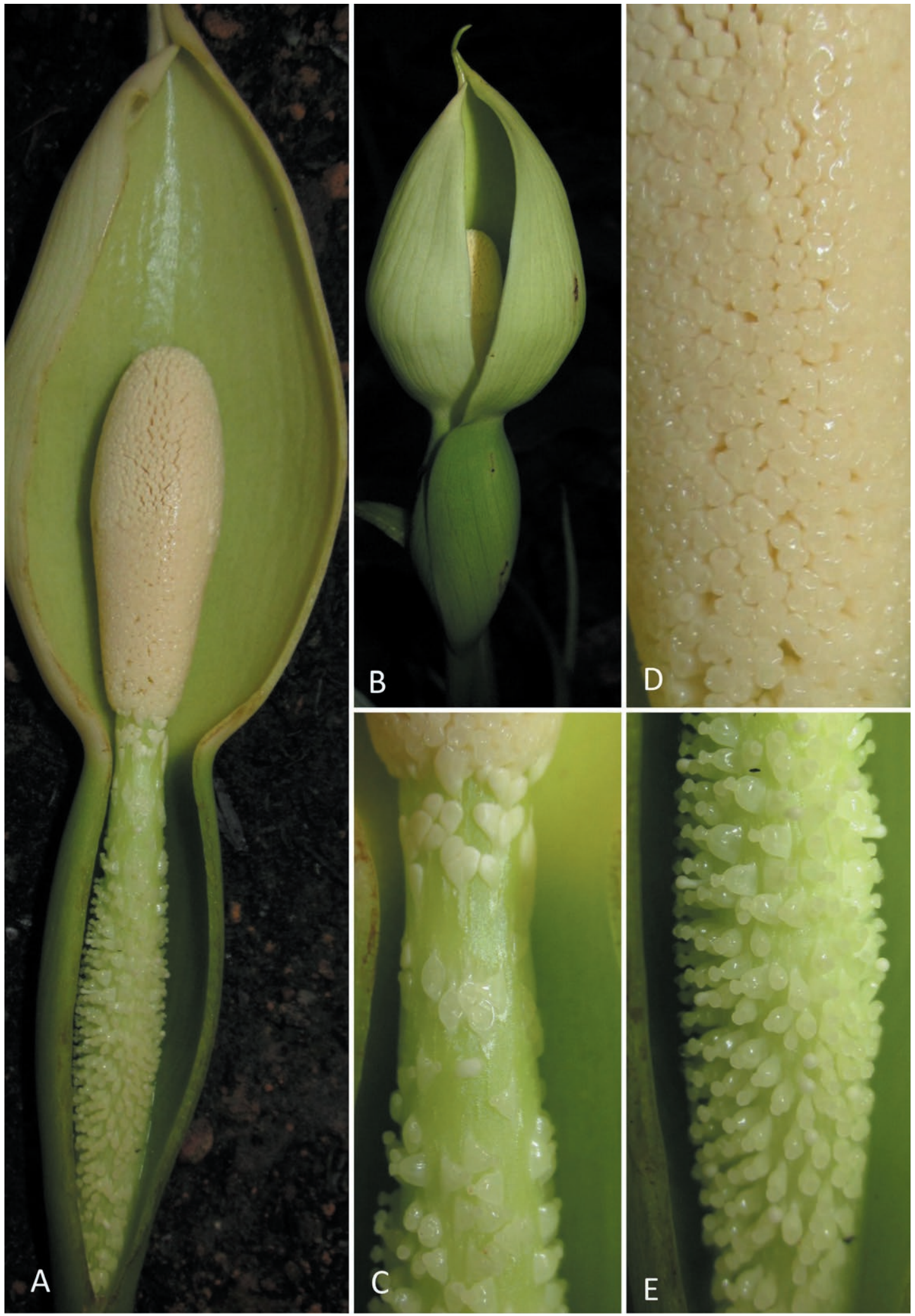

Figure 7. Schismatoglottis laxipistillata S.Y.Wong, P.C.Boyce \& Y.C.Hoe. A. Bloom at pistillate anthesis, nearside spathe artificially removed. B. Bloom at pistillate anthesis. C. Detail of upper part of pistillate zone, interstice with flattened staminodes, and lowermost part of staminate zone. D. Detail of staminate zone. E. Detail of pistillate zone. All from AR-4331 


\section{Etymology}

The specific epithet refers to the uniquely, in the species group, laxly arranged pistils.

\section{Distribution}

Schismatoglottis laxipistillata is only known from its locality at Hutan Lipur Rekreasi Tupah where it is threatened by land clearance for quarrying.

\section{Ecology}

Perhumid lowland forest, occurring beside the margin of the waterfall and stream and restricted to steep Ordovician-Devonian Karst slopes in pockets of occasionally inundated mud. About $100 \mathrm{~m}$ asl.

\section{Notes}

Initially it was thought that the lax pistillate florets were an artefact of the first specimen encountered, but their occurrence is highly uniform through the known population.

\section{Additional specimen examined (paratypes)}

MALAYSIA. Kedah. Merbok, Bedong, Hutan Lipur Rekreasi Tupah, 544'39.30"N 100²6'30.24'E, $104 \mathrm{~m}$ asl, 11 Dec 2013, Hoe Yin Chen AR-4330 (KEP, SAR).

Schismatoglottis pantiensis S.Y.Wong, P.C.Boyce \& Y.C.Hoe, sp. nov.

Type: Malaysia, Johor, Kota Tinggi, Hutan Simpan Panti, starting point of trail to Mount Panti, $1^{\circ} 48^{\prime} 35.70^{\prime \prime} \mathrm{N}$ 10351'5.94"E, 4 Dec 2013, Hoe Yin Chen AR-4322 (holotype KEP; isotype SAR). (Figures 8, 9 and 10F).

\section{Diagnosis}

The spadix of Schismatoglottis pantiensis is superficially similar to that of $S$. lowiae differing by the pistillate zone extending to almost half the length of the spadix (vs about $1 / 3$ ), by the interstice up to three times longer, and with the interstice staminodes and staminate florets readily distinguished (vs interstice staminodes and staminate florets almost indistinguishable until pollen is shed from the anthers), and consequently their respective zones easily discerned, and by a short bulletshaped appendix comprised of clearly individuated staminodes (vs appendix blunt-cylindrical with the individual staminodes not discernible.

\section{Description}

Medium to moderately robust, evergreen, stoloniferous herb forming clumps, 35-40 cm tall. Stems hypogeal, hapaxanthic, $1-1.5 \mathrm{~cm}$ diam. Leaves 3-7 together; petiole D-shaped, smooth, $15-18 \mathrm{~cm}$ long, green, weakly channelled throughout its length, longitudinal striations raised and darker distally; petiolar sheath, $8 \mathrm{~cm}$ long $\times$ 0.5 wide, sheathing for $1 / 3-1 / 2$ of petiole length, persistent, membranous, fully attached with a very short ligule, equal at both sides, slightly in-rolled or sometimes straight, tapering, green with scattered greenish broken striations blades ovato-sagittate to ovato-cordate (sometimes oblong-lanceolate with the base cordate), $16-23 \mathrm{~cm}$ long $\times 9-13 \mathrm{~cm}$ wide, softly coriaceous, adaxially glossy green, abaxially paler, posterior lobes subtriangular, 4-6 $\mathrm{cm}$ long, sinus $4.5-5 \mathrm{~cm}$ across, apex of anterior lobe acute for $2 \mathrm{~cm}$, ultimately mucronate for $5 \mathrm{~mm}$; midrib adaxially flush with blade, raised abaxially, $4 \mathrm{~mm}$ at the insertion of blade; primary lateral veins 14 per side, diverging at $30^{\circ}-80^{\circ}$ from the midrib, raised adaxially towards the midrib, marginally impressed, entirely raised abaxially; interprimary veins raised adaxially, alternating irregularly with primaries; secondary veins rather; vein-like pellucid canals not visible. Inflorescences up to 3 per synflorescence, erect, emitting an esteric smell during pistillate anthesis, this absent during staminate anthesis; peduncle $13 \mathrm{~cm}$ long $\times 6 \mathrm{~mm}$ wide, terete, green, erect at anthesis; spathe $12 \mathrm{~cm}$ long; lower spathe narrowly ovoid, $5 \mathrm{~cm}$ long $\times 1.8 \mathrm{~cm}$ wide, green, longitudinally ridged externally?, separated from spathe limb by a constriction coinciding with the lower staminate zone; spathe limb turbinate, $7 \mathrm{~cm}$ long $\times 2.7 \mathrm{~cm}$ wide, mucronate for $4 \mathrm{~mm}$, pale greenish yellow at pistillate anthesis, slightly pallid prior to staminate anthesis, caducous and falling in a single piece at onset of staminate anthesis; spadix $7 \mathrm{~cm}$ long, shorter than spathe, sessile; pistillate zone cylindric, $3.5 \mathrm{~cm}$ long $\times 7 \mathrm{~mm}$ wide, length of spadix, light green; pistils sub-globose, $1 \mathrm{~mm}$ long $\times$ 0.5-1.2 mm wide, densely arranged; style short, light green; stigma sub-globose from above, truncate, smaller than ovary, $0.3 \mathrm{~mm}$ diam., wet with stigmatic secretion at the onset of pistillate anthesis; interpistillar staminodes absent; interstice cylindric, $0.8-1 \mathrm{~cm}$ long $\times 6 \mathrm{~mm}$ wide, very slightly narrower than pistillate and staminate zone, not naked, comprised 10-12 whorls of sub-globose staminodes that resemble staminodes of appendix, densely packed, staminodes not impressed; staminodes $0.5-1 \mathrm{~mm}$ wide, sub-globose, light yellow; staminate zone sub-cylindric, narrower at proximal but wider at distal end, $1.7 \mathrm{~cm}$ long $\times 7-9$ $\mathrm{mm}$ wide, $1 / 4$ length of spadix, yellowish white; staminate florets butterfly-shaped from above, $1 \mathrm{~mm}$ long $\times$ 

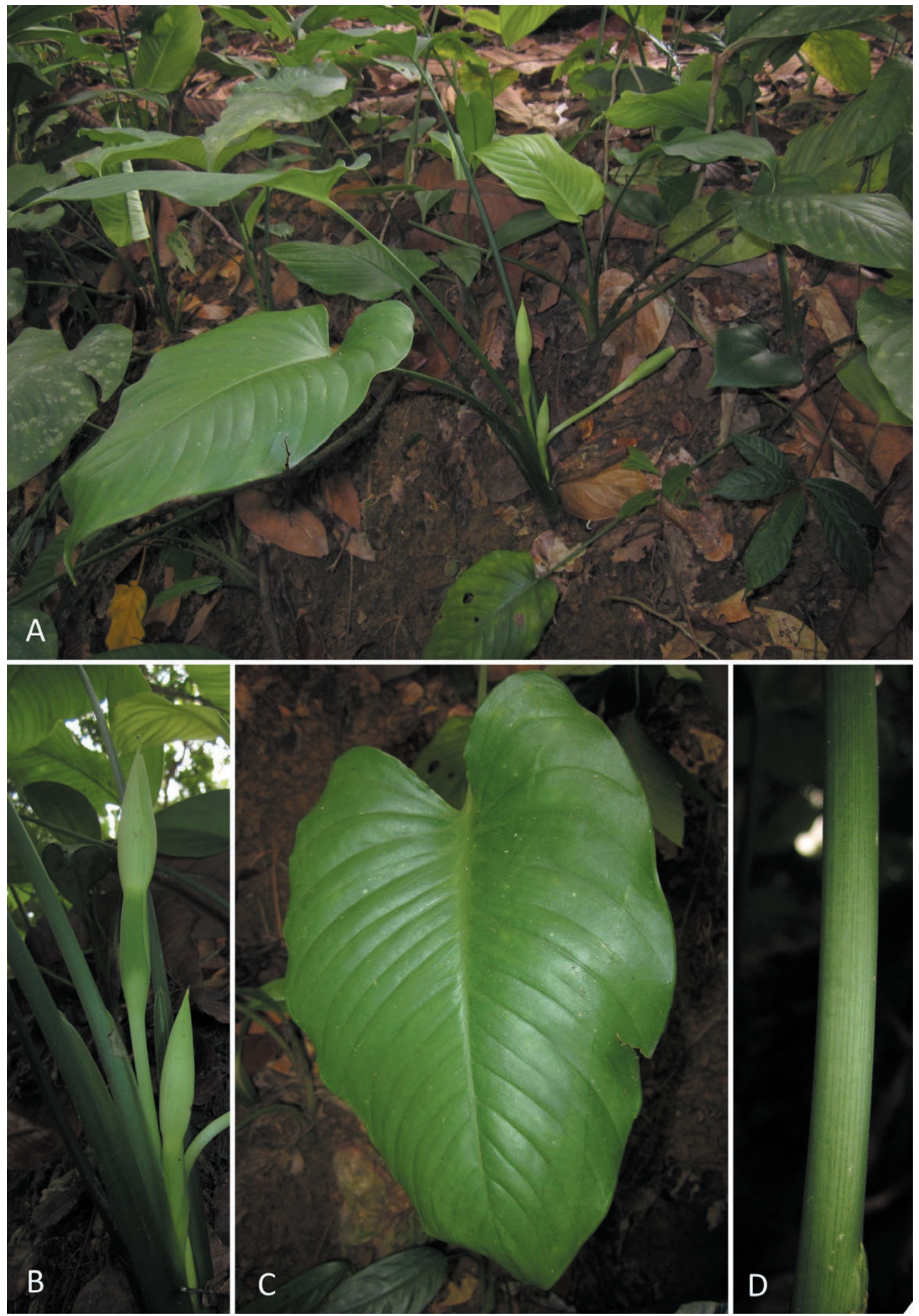

Figure 8. Schismatoglottis pantiensis S.Y.Wong, P.C.Boyce \& Y.C.Hoe. A. Plant in habitat. B. Base of plant with emerging sequentially produced blooms. C. Leaf blade adaxial surface. D. Detail of petiole. All from AR-4322. 


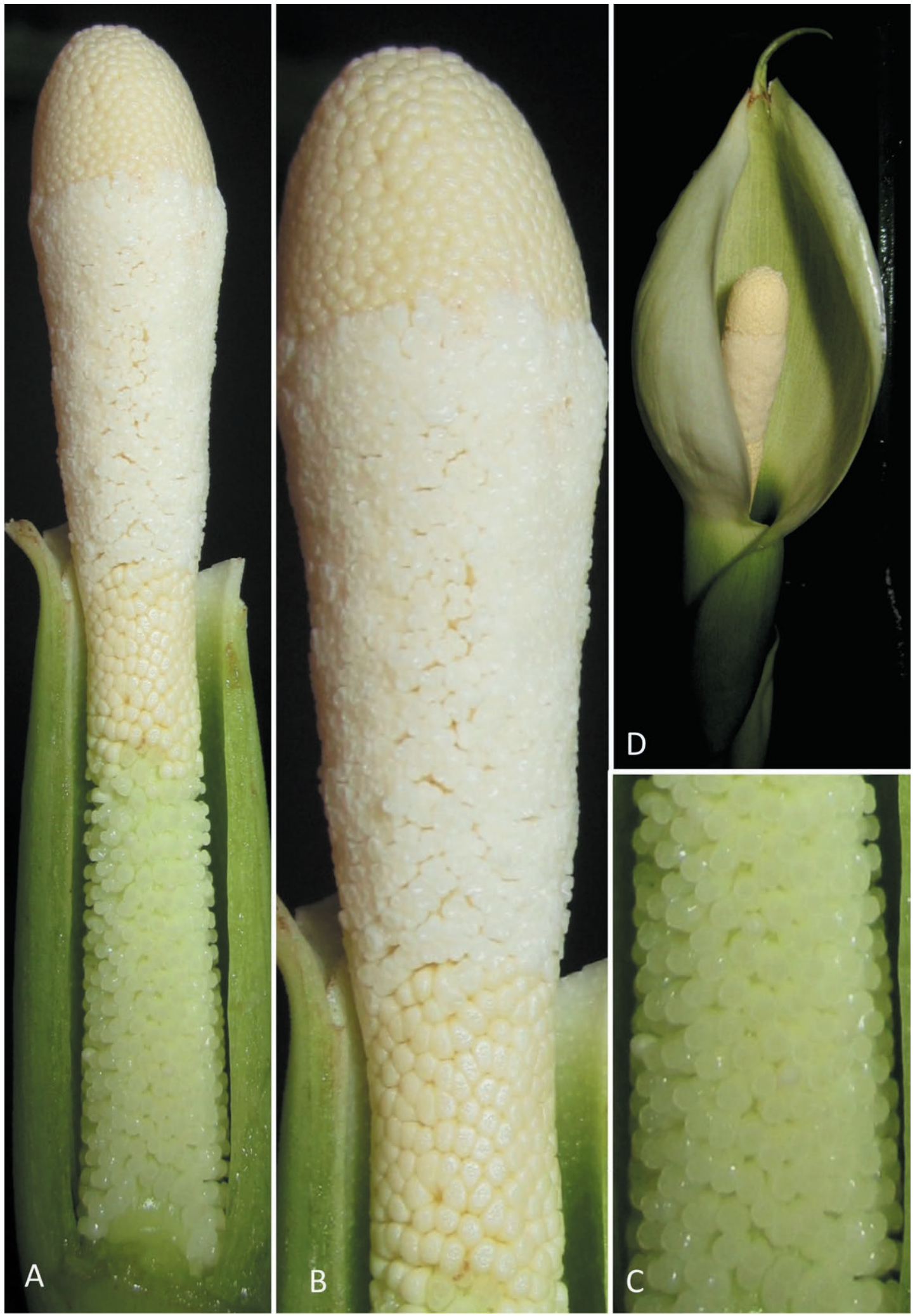

Figure 9. Schismatoglottis pantiensis S.Y.Wong, P.C.Boyce \& Y.C.Hoe. A. Bloom at pistillate anthesis, nearside lower spathe and spathe limb artificially removed. B. Detail of interstice, staminate zone, and appendix. C. Detail of pistillate zone. D. Bloom at pistillate anthesis. All from $A R-4322$. 

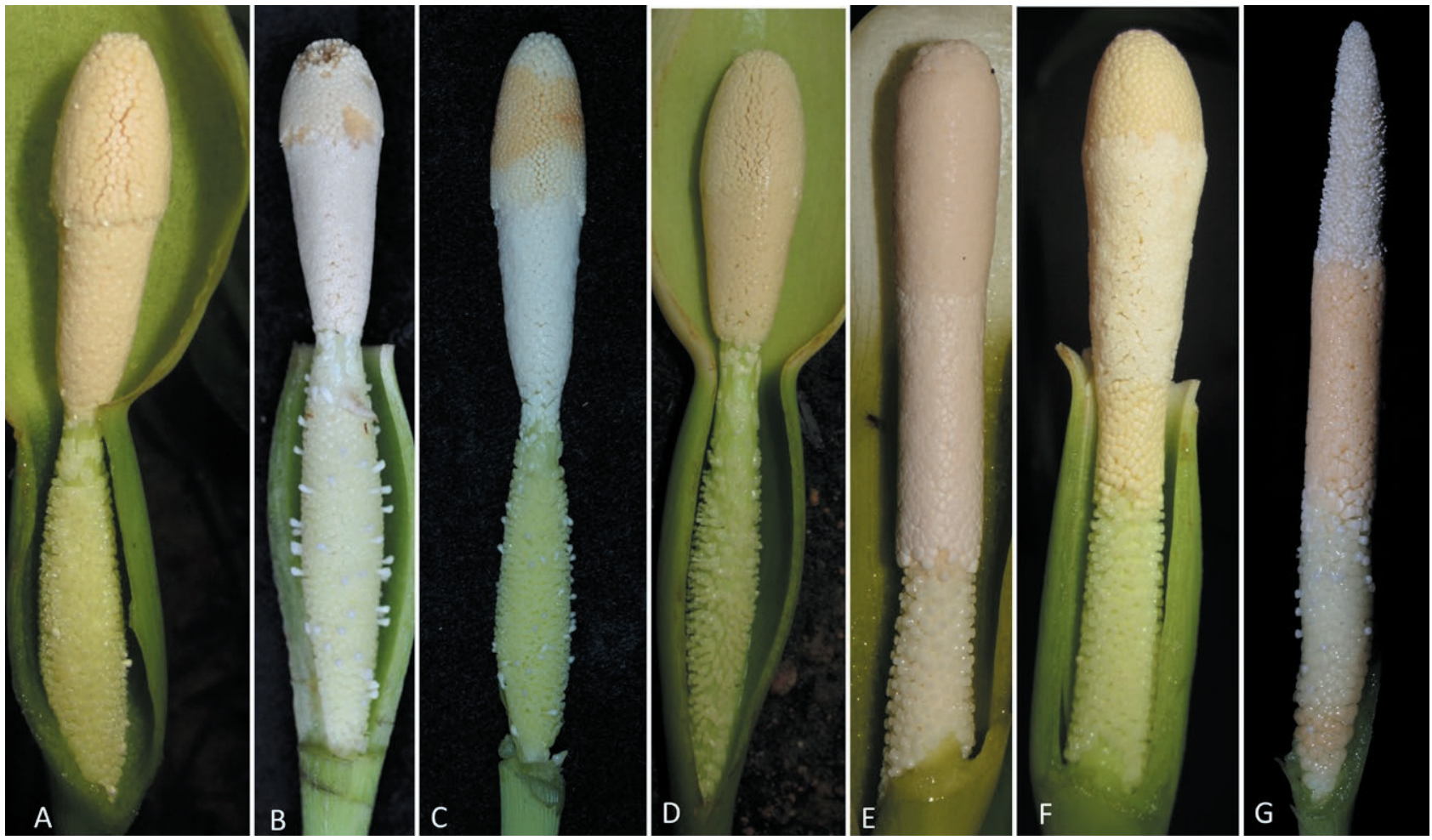

Figure 10. Spadix comparisons. A. Schismatoglottis caesia. B. Schismatoglottis cordifolia. C. Schismatoglottis guabatuensis. D. Schismatoglottis laxipistillata. E. Schismatoglottis lowiae. F. Schismatoglottis pantiensis. G. Schismatoglottis wallichii.

$0.5 \mathrm{~mm}$ wide, densely arranged, each comprising 2 truncate stamens, tops depressed, connective narrow; pollen powdery, white; appendix bullet-shaped, $0.9 \mathrm{~cm}$ long $\times 0.9 \mathrm{~cm}$ wide, $1 / 7$ length of spadix, base about equalling top of staminate zone, yellowish white; staminodes sub-globose, $1 \mathrm{~mm}$ diam., densely arranged. Infructescences $1-3$ together, $3.2-5.2 \mathrm{~cm}$ long $\times 0.8-1.5 \mathrm{~cm}$ wide, declinate; lower spathe entirely persistent, splitting and reflexed when ripe; fruits $2 \mathrm{~mm}$ long $\times 1-1.8 \mathrm{~mm}$ wide, light green; seeds ovoid ellipsoid, $0.4 \mathrm{~mm}$ diam., 4-17 per fruit, encased with greenish yellow gel.

\section{Etymology}

The specific epithet is derived from the name of the type locality plus the Latin suffix, -ensis, to indicate originating from.

\section{Distribution}

Schismatoglottis pantiensis is only known from Hutan Simpan Panti, Kota Tinggi, Johor.

\section{Ecology}

Lowland tropical forest on deep permanently moist podzols, below $25 \mathrm{~m}$ asl.

\section{Additional specimens examined (paratypes)}

MALAYSIA. Johor. Kota Tinggi, Hutan Simpan Panti, starting point of trail to Mount Panti, $1^{\circ} 48^{\prime} 35.70^{\prime \prime} \mathrm{N}$ 10351'5.94"E, 4 Dec2013, Hoe Yin Chen AR-4323 (KEP, SAR) \& AR-4326 (KEP, SAR) \& AR-4337 (KEP, SAR). Kota Tinggi, Hutan Simpan Panti, starting point of the trail to Mount Panti, $1^{\circ} 48^{\prime} 33.90^{\prime \prime} \mathrm{N} 103^{\circ} 51^{\prime} 6.24^{\prime \prime} \mathrm{E}, 4 \mathrm{Dec}$ 2013, Hoe Yin Chen AR-4324 (KEP, SAR) \& AR-4325 (KEP, SAR) \& AR-4327 (KEP, SAR) \& AR-4328 (KEP, SAR).

Key to the Peninsula Malaysian species of Schismatoglottis Calyptrata Clade

1a. Spadix fertile to the tip, or with at most a few terminal staminodes; spathe limb splitting into numerous circumferential pieces before falling. Perak, vicinity of Taiping.....

Schismatoglottis wallichii

1b. Spadix with a distinct sterile appendix; spathe limb caducous in a single piece.

2a. Leaf blades glaucous. East Kelantan. Triassic granite Schismatoglottis caesia

2b. Leaf blade not glaucous 3 
3a. Pistillate florets laxly arranged. Kedah, Hutan Lipur Rekreasi Tupah Merbok, Ordovician-Devonian Karst......... Schismatoglottis laxipistillata

3b. Pistillate florets densely arranged. .4

4a. Interpistillar staminodes present. .5

4b. Interpistillar staminodes absent .6

5a. Pistillate floret zone green, accounting for less than half of the spadix length; interpistillar staminodes only slightly taller than the associated pistils; appendix conical 1.5 times longer than wide. Batu Caves, Silurian limestone ......

Schismatoglottis guabatuensis

5b. Pistillate floret zone white, accounting for more than half of the spadix length; interpistillar staminodes twice as tall as the associated pistils; appendix hemispherical and about as wide as long. Hulu Perak, Cambrian Baling sandstones..

Schismatoglottis cordifolia

6a. Pistillate zone accounting for almost half the length of the spadix; interstice staminodes and staminate florets readily distinguished, and their respective zones easily discerned; appendix short bullet-shaped comprised of clearly differentiated staminodes. Johor, Hutan Simpan Panti, permanently moist podzols. Schismatoglottis pantiensis

6b. Pistillate zone accounting for about $1 / 3$ the length of the spadix; interstice staminodes and staminate florets closely similar, the zones not readily separable at first sight; appendix blunt-cylindrical with the individual staminodes not discernible. Heavy clay soils over granite; widespread but localized in Kelantan, Perak, and northern Selang........

Schismatoglottis lowiae

\section{ACKNOWLEDGEMENTS}

The second author extends his thanks to Tan Sri Datuk Amar Leonard Linggi Anak Jugah and Malesiana Tropicals Sdn Bhd for continued support and encouragement.

\section{REFERENCES}

Hay A. 1996. The genus Schismatoglottis Zoll. \& Moritzi (Araceae: Schismatoglottideae) in Peninsular Malaysia and Singapore. Sandakania. 7: 1-30.

Hay A, Yuzammi. 2000. Schismatoglottideae (Araceae) in Malesia I - Schismatoglottis. Telopea. 9: 1-177.

Hoe YC, Gibernau M, Wong SY. 2018. Diversity of pollination ecology in the Schismatoglottis Calyptrata Complex Clade (Araceae). Plant Biology. 20(3): 563-578.

Hoe YC, Gibernau M, Wong SY. 2020. Thermogenesis in four species of Schismatoglottis Calyptrata Clade
(Schismatoglottideae: Araceae). Feddes Repertorium. 131(4): 268-277.

Hoe YC, Wong SY. 2016. Floral biology of Schismatoglottis baangongensis (Araceae) in West Sarawak, Malaysian Borneo. Plant Systematics and Evolution. 302: 1239-1252.

Hooker JD. 1893. Araceae. In: The Flora of British India 6. Reeve \& Co., London, pp. 490-558.

Ridley HN. 1911. A scientific expedition to Temengoh, Upper Perak. Journal of the Straits Branch of the Royal Asiatic Society. 57: 5-122.

Tate RB, Tan DNK, Ng TF. 2008. Geological Map of Peninsular Malaysia. Scale 1:1,000,000. Geological Society of Malaysia and University of Malaya.

Wong SY, Boyce PC. 2017. Studies on Schismatoglottideae (Araceae) of Peninsular Malaysia I: On the identity of Schismatoglottis wallichii var. oblongata and a new species S. lowae. Aroideana. 40(1): 29-38.

Wong SY, Boyce PC. 2020. Studies on Schismatoglottideae (Araceae) of Peninsular Malaysia II: Schismatoglottis guabatuensis [Calyptrata Clade], a new locally endemic limestone-obligated species. Nordic Journal of Botany. 2020: e02808: 1-5.

Wong SY, Boyce PC. 2021. Studies of the Homalomeneae (Araceae) of Peninsular Malaysia VII - Homalomena joanneae [Chamaecladon Clade], a new locally endemic limestone-obligated species Webbia. 76(1): 77-81.

Wong SY, Hay A, Boyce PC. 2018. An annotated checklist for Schismatoglottis. Aroideana. 41(2\&3): 34-200.

Wong SY, Hoe YC, Boyce PC. 2016. Studies on Schismatoglottideae (Araceae) of Borneo LIX - A preliminary conspectus of Schismatoglottis Calyptrata Clade species for Sarawak. Aroideana. 39(2): 71-100. 